\title{
Bile acid metabolism by fresh human colonic contents: a comparison of caecal versus faecal samples
}

\author{
L A Thomas, M J Veysey, G French, P B Hylemon, G M Murphy, R H Dowling
}

\begin{abstract}
Background-Deoxycholic acid (DCA), implicated in the pathogenesis of gall stones and colorectal cancer, is mainly formed by bacterial deconjugation (cholylglycine hydrolase (CGH)) and $7 \alpha-$

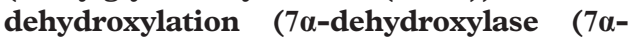
DH)) of conjugated cholic acid (CA) in the caecum/proximal colon. Despite this, most previous studies of CGH and $7 \alpha-\mathrm{DH}$ have been in faeces rather than in caecal contents. In bacteria, CA increases $7 \alpha-\mathrm{DH}$ activity by substrate-enzyme induction but little is known about CA concentrations or $\mathrm{CA} / 7 \alpha-\mathrm{DH}$ induction in the human colon. Aims and methods-Therefore, in fresh "faeces", and in caecal aspirates obtained during colonoscopy from 20 patients, we: (i) compared the activities of CGH and $7 \alpha-\mathrm{DH}$, (ii) measured $7 \alpha-\mathrm{DH}$ in patients with "low" and "high" percentages of DCA in fasting serum (less than and greater than the median), (iii) studied CA concentrations in the right and left halves of the colon, and examined the relationships between (iv) $7 \alpha-\mathrm{DH}$ activity and CA concentration in caecal samples (evidence of substrate-enzyme induction), and (v) $7 \alpha-D H$ and per cent DCA in serum.
\end{abstract}

Gastroenterology Unit, Guy's Hospital Campus, UMDS, London, UK L A Thomas M J Veysey G M Murphy R H Dowling

Microbiology Department, St Thomas' Hospital Campus, UMDS, London, UK G French

Departments of Microbiology and Medicine, Virginia Commonwealth University, Richmond, Virginia, USA P B Hylemon

Correspondence to: Professor R H Dowling, Academic Gastroenterology, 4th Floor N Wing, St Thomas' Hospital, London SE1 7EH, UK.

h.dowling@umds.ac.uk/ h.dowling@talk21.com

Accepted for publication 15 March 2001
Results-Although mean CGH activity in the proximal colon $\left(18.3(\right.$ SEM 4.40$) \times 10^{-2}$ U/mg protein) was comparable with that in "faeces" $\left(16.0(4.10) \times 10^{-2} \mathrm{U} / \mathrm{mg}\right.$ protein), mean $7 \alpha-D H$ in the caecum $(8.54$ (1.08) $\times 10^{-4} \mathrm{U} / \mathrm{mg}$ protein) was higher $(p<0.05)$ than that in the left colon $(5.72$ $(0.85) \times 10^{-4} \mathrm{U} / \mathrm{mg}$ protein). At both sites, $7 \alpha-\mathrm{DH}$ was significantly greater in the "high" than in the "low" serum DCA subgroups. CA concentrations in the right colon $(0.94(0.08) \mu \mathrm{mol} / \mathrm{ml})$ were higher than those in the left $(0.09(0.03) \mu \mathrm{mol} / \mathrm{ml}$; $\mathbf{p}<0.001$ ) while in the caecum (but not in the faeces) there was a weak $(r=0.58)$ but significant $(p<0.005)$ linear relationship between $7 \alpha-\mathrm{DH}$ and $\mathrm{CA}$ concentration. At both sites, $7 \alpha-\mathrm{DH}$ was linearly related $(p<0.005)$ to per cent DCA in serum.

Interpretation/summary-These results: (i) confirm that there are marked regional differences in bile acid metabolism between the right and left halves of the colon, (ii) suggest that caecal and faecal $7 \alpha-\mathrm{DH}$ influence per cent DCA in serum (and, by inference, in bile), and (iii) show that the substrate CA induces the enzyme $7 \alpha-\mathrm{DH}$ in the caecum.

(Gut 2001;49:835-842)
Keywords: deoxycholic acid; $7 \alpha$-dehydroxylation; gall stones; colorectal cancer

Colonic bacteria play a major role in bile acid metabolism. Thus anaerobic bacterial enzymes convert conjugated primary bile acids, such as the glycine and taurine conjugates/amidates of cholic acid (CA), into unconjugated secondary bile acids, such as deoxycholic acid (DCA), in two major steps:

(i) deconjugation, whereby the enzyme cholylglycine hydrolase (CGH) deconjugates (or deamidates) the conjugated bile acids to yield the corresponding unconjugated species, followed by the

(ii) $7 \alpha$-dehydroxylation pathway.

It is believed that these enzymatic reactions take place mainly in the caecum and ascending colon. ${ }^{12}$ Logically therefore the activities of these enzymes should be measured in the proximal colon or in samples obtained from the caecal lumen, rather than in stools. Before the present studies however, human CGH and $7 \alpha$-dehydroxylase $(7 \alpha-\mathrm{DH})$ activities were measured in isolated bacterial strains (single or mixed), ${ }^{3-7}$ or in faeces, ${ }^{8}$ rather than in colonic contents, no doubt because in humans the caecum and ascending colon are relatively inaccessible. In at least two respects however the luminal milieu in the proximal large bowel is different from that in the distal colon (or in fresh faeces). Firstly, the ratio of anaerobic: aerobic bacteria is greater in the faeces than in the caecum $^{9}$ which is of relevance as $7 \alpha$-dehydroxylation is carried out only by anaerobic bacteria. Secondly, the luminal $\mathrm{pH}$ is lower in the proximal than in the distal colon. ${ }^{10}{ }^{11}$ In theory, such changes in luminal $\mathrm{pH}$ could affect the growth of bacteria in the colon. ${ }^{12}$ They could also influence the reaction rates of the two bile acid metabolising enzymes, both of which are $\mathrm{pH}$ dependent. ${ }^{12}$

The $7 \alpha$-dehydroxylation pathway is inducible by its principal substrate CA. ${ }^{13}$ However, by the time bile acids reach the faeces almost all have been converted from primary to secondary bile acids. $^{314}$ In theory therefore the absence of CA from the contents of the left colon/faeces means that there is no longer any substrate available for induction of $7 \alpha-\mathrm{DH}$. If such induction is important quantitatively, one might expect corresponding inequalities in CA $7 \alpha-\mathrm{DH}$ activity between the right and left

Abbreviations used in this paper: CA, cholic acid; DCA, deoxycholic acid; $7 \alpha-\mathrm{DH}, 7 \alpha$-dehydroxylase; CGH, cholylglycine hydrolase; TLC, thin layer chromatography. 
halves of the colon. Despite this, there is no information about differences in bile acid metabolising enzyme activities between caecal contents and faeces.

The results of studies by Berr and colleagues ${ }^{8}$ showed that faecal $7 \alpha-\mathrm{DH}$ activity is significantly greater in patients with high versus those with low DCA pool sizes and/or DCA: CA molar ratios. To see if similar differences are present in caecal and faecal contents, we calculated the median per cent DCA in fasting serum $(19.7 \%)$ and used this to divide patients retrospectively into "low" and "high" DCA subgroups, and compared caecal and faecal $7 \alpha-\mathrm{DH}$ activities in the two populations.

The aims of this hypothesis driven study therefore were to determine whether:

(i) the activities of the bile acid metabolising enzymes (CGH and $7 \alpha-\mathrm{DH})$, and the concentrations of unconjugated $\mathrm{CA}$, are different in caecal and faecal samples,

(ii) in patients with high versus those with low circulating DCA levels (as indicated by the per cent DCA in fasting serum ${ }^{8}$ ), the activities of the two enzyme pathways in question are different,

(iii) there is a relationship between $7 \alpha-\mathrm{DH}$ activity (in both caecal and faecal samples) and serum DCA,

(iv) as a result of bacterial biotransformation (and/or absorption), the concentrations of endogenous CA change in the luminal contents, from the right to the left halves of the colon, and

(v) there is evidence of induction of the $7 \alpha-\mathrm{DH}$ enzyme pathway by its substrate (CA) in caecal aspirates.

\section{Patients and methods}

PATIENTS

Twenty patients were studied (11 stone free "controls" and nine with cholesterol rich gall bladder stones). Age range was 57-69 years and 15 were women. All 20 had undergone clinically indicated colonoscopy (during which caecal contents were sampled by aspiration, see below) and had been found, in retrospect, to have normal colons.

The decision to carry out the present study was taken halfway through a larger companion study ${ }^{15}$ which involved a total of 40 patients. However, once the decision had been reached, the next 20 patients were recruited sequentially with no further selection.

SAMPLING PROXIMAL COLONIC CONTENTS

As a prelude to colonoscopy, the contents of the left colon were washed out using a phosphate enema, with the aim of leaving those in the right colon undisturbed. The use of this instant enema enabled us to examine the large bowel mucosa of the left colon endoscopically, after which the scope was advanced into the unprepared right colon, proximal to the hepatic flexure.

To facilitate collection of the caecal/proximal colonic contents, $20 \mathrm{ml}$ of sterile saline were injected into the colonic lumen through the biopsy channel of the endoscope. The caecal contents were then homogenised in situ using rotatory movements of the tip of the colonoscope, and repeated aspiration/reinjection cycles of the luminal contents through the biopsy channel. The resultant mixture was aspirated into a trap pregassed with nitrogen. In order to transfer samples from the endoscopy department to the microbiology laboratory under anaerobic conditions, we used the GasPak anaerobic pouch system. The homogenised caecal aspirates reached the laboratory within one hour of collection.

SAMPLING FRESH "FAECES"

As noted above, before patients were endoscoped they were given a phosphate enema which stimulated the passage of "faeces" (left colonic contents). A $1.0 \mathrm{~g}$ aliquot of this enema washout material was immediately homogenised with $25 \%(\mathrm{w} / \mathrm{v})$ saline, and rapidly (again within one hour) transferred to an anaerobic environment, using the GasPak anaerobic pouch system. In this way, the "caecal" (proximal colonic aspirate) and the "faecal" (aliquot from the left colonic washout) samples were collected from the same patient, at the same time.

BILE ACID METABOLISING ENZYME ACTIVITIES IN CAECAL ASPIRATES AND FAECES

The activities of both bile acid metabolising enzymes (see below) were measured in proteins precipitated from sonicates of the caecal and faecal samples, using saturated ammonium sulphate, as previously described. ${ }^{16}$ For both enzymes, the results are expressed as units (U) of enzyme activity where I $U=1 \mu \mathrm{mol}$ of product formed per $\mathrm{mg}$ of bacterial protein per minute.

\section{Cholylglycine hydrolase}

The substrate for the deconjugation reaction was $10 \mathrm{mM}$ taurocholic acid $(0.5 \mathrm{ml}$ substrate incubated with $0.5 \mathrm{ml}$ of the protein extract), as previously described. ${ }^{17}$ The product of this reaction (CA) was extracted using a $\mathrm{C} 18$ column, ${ }^{18}$ isolated by thin layer chromatography (TLC) ${ }^{19}$ and measured with the $3 \alpha-$ hydroxysteroid dehydrogenase assay ${ }^{20}$ at 340 nm.

Cholic acid 7a-dehydroxylation

The reaction conditions for this enzyme were the same as those described elsewhere. ${ }^{17}$ In brief, $0.5 \mathrm{ml}$ of the protein extract was incubated with non-isotopic CA ( $2 \mathrm{mM}$, used to catalyse the reaction by substrate-enzyme induction ${ }^{13}$ ), plus ${ }^{14} \mathrm{C}-\mathrm{CA}(200000 \mathrm{dpm})$. Bile acids in the reaction mixture were then extracted twice using ethyl acetate, separated, and identified using TLC, and the $\left[{ }^{14} \mathrm{C}\right]$ radioactivity in the DCA fraction measured in a liquid scintillation counter.

Cholic acid concentrations in caecal and faecal samples

To measure levels of endogenous CA in caecal and faecal samples, a blank was run as follows: a $0.5 \mathrm{ml}$ aliquot of the sample was incubated with $0.5 \mathrm{ml}$ of sterile saline using the 
conditions described above for the deconjugation reaction (except that no substrate was added).

As before, after the incubation was complete, $1 \mathrm{ml}$ of $0.1 \mathrm{M} \mathrm{NaOH}$ was added to the reaction mixture and the sample centrifuged to separate the supernatant and precipitate phases. The supernatant fluid was then loaded onto a C18 column to extract bile acids present in the original sample.

Bile acids were separated using TLC, and the area corresponding to the CA standard was scraped from the TLC plate, reacted with $3 \alpha$-hydroxysteroid dehydrogenase, and measured spectrophotometrically as previously described. ${ }^{20}$

\section{Serum DCA}

Concentrations of DCA (total, conjugated, and unconjugated fractions) were measured in fasting serum using gas chromatography-mass spectrometry ${ }^{2122}$ and the proportions calculated, as previously described. ${ }^{23}$ In this paper however we refer only to the unconjugated fraction of DCA in fasting serum.

As noted above, the median per cent DCA in fasting serum was $19.7 \%$, and despite the fact that concentrations of DCA in fasting serum were normal in all 20 individuals, this median was used to divide patients, retrospectively, into "low" and "high" serum DCA subgroups, as follows:

(i) "low" DCA subgroup ( $<19.7 \%$ DCA in fasting serum: $n=10)$; mean (SEM) serum DCA concentration $0.28(0.06) \mu \mathrm{M}$.

(ii) "high" DCA subgroup ( $>19.7 \%$ DCA in fasting serum: $n=10)$; mean (SEM) serum DCA concentration $0.54(0.10) \mu \mathrm{M}$.

We then used univariate analyses to examine the inter-relationships between per cent DCA in fasting serum and the activities of the two bile acid metabolising enzymes in both caecal and faecal samples.

Evidence of substrate-enzyme induction in caecal aspirates

To test the hypothesis that the substrate (CA) might induce the enzyme system $(7 \alpha-\mathrm{DH})$ in the proximal colon, we used univariate analysis to examine the relationship between these variables in caecal aspirates.

Relationship between $7 a-D H$ activity and per cent DCA in fasting serum

The role of caecal $7 \alpha-\mathrm{DH}$ activity in DCA metabolism was addressed in detail in our companion paper. ${ }^{15}$ To avoid duplication therefore, the relationship between the dehydroxylating enzyme system and serum DCA is confined in this study to the correlation coefficients between $7 \alpha-\mathrm{DH}$ (in both caecal and faecal samples) and per cent DCA in serum.

ETHICAL CONSIDERATIONS

The study was approved by the research ethics committee of Guy's and St Thomas' Hospitals. All patients gave their written informed consent.

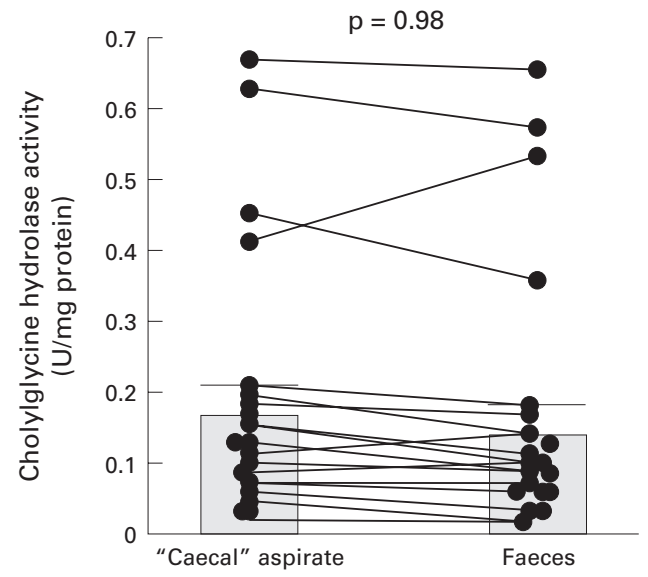

Figure 1 Paired results for cholylglycine hydrolase activity in "caecal" and faecal samples: individual data points with means (SEM).

STATISTICAL ANALYSES

Unless otherwise stated, all results are expressed as mean (SEM).

The significance of differences in results between the two groups was tested with the heteroscedastic $t$ test using Excel Software version 5.0 (Microsoft Corporation, 1 Microsoft Way, Redmond, WA 98052-6399, USA); p values $<0.05$ were considered to be statistically significant.

Univariate analyses were performed using SPSS software; the statistical significance of the correlation coefficients was examined using an unpaired two tailed Student's $t$ test.

\section{Results}

CHOLYLGLYCINE HYDROLASE

The paired results, comparing CGH activity in caecal and faecal samples from the same individuals, are shown graphically in fig 1 .

As the results in fig 1 show, most of the CGH results were tightly bunched $(<0.2$ enzyme units/mg protein). However, in a subgroup of four patients (one stone free, three stone carriers), CGH activities were appreciably higher (range $0.35-0.66 \mathrm{U} / \mathrm{mg}$ protein) than those in the remaining 16 patients. None the less, when the activities in all 20 patients were pooled, there were no significant differences between mean enzyme activities for the caecal (0.18 (SEM 0.04) enzyme units/mg protein) and faecal (0.16 (0.04) enzyme units/mg protein) samples. Furthermore, when the CGH results in the low and high DCA groups were compared (table 1), again there was no difference in mean values between the two subgroups.

Table 1 Cholylglycine hydrolase (CGH) activities in caecal and "faecal" samples from the low and high serum deoxycholic acid (DCA) subgroups (see text)

\begin{tabular}{llll}
\hline & \multicolumn{4}{l}{ CGH activity } & (U/mg protein) & \\
\cline { 2 - 4 } & $\begin{array}{l}\text { Low serum } \\
\text { DCA }\end{array}$ & $\begin{array}{l}\text { High serum } \\
\text { DCA }\end{array}$ & p Value \\
\hline Caecal aspirate & $0.18(0.06)$ & $0.20(0.08)$ & NS \\
"Faeces" & $0.17(0.06)$ & $0.21(0.09)$ & NS \\
\hline
\end{tabular}




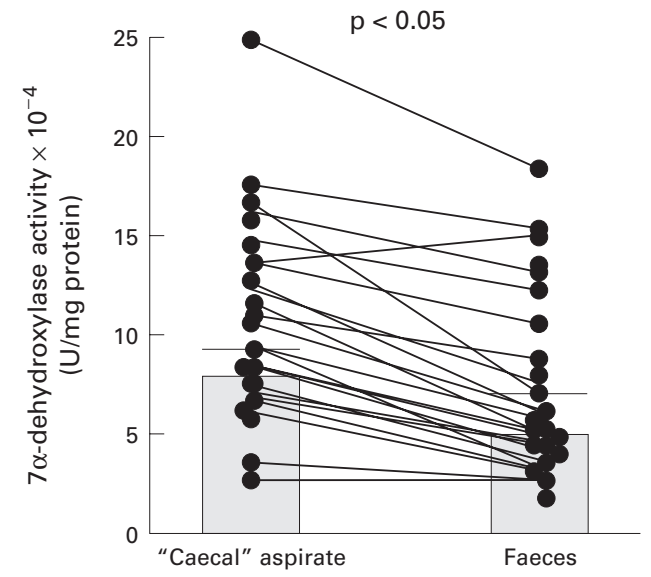

Figure 2 Paired results for 7a-dehydroxylase activity in the "caecal" and faecal samples: individual data points with means (SEM).

CHOLIC ACID $7 \alpha$-DEHYDROXYLATION

Corresponding paired results for $7 \alpha-\mathrm{DH}$ activity in caecal and faecal samples $(n=20)$ are shown in fig 2.

With three exceptions, $7 \alpha-\mathrm{DH}$ activity was always higher in caecal aspirates than in matched faecal samples such that for all 20 patients the mean value in the caecum (8.54 (1.08) $\times 10^{-4} \mathrm{U} / \mathrm{mg}$ protein) was $49 \%$ greater than that in faeces $\left(5.72(0.85) \times 10^{-4} \mathrm{U} / \mathrm{mg}\right.$ protein; $\mathrm{p}<0.05$ ).

CAECAL AND FAECAL $7 \alpha-$ DH ACTIVITIES IN THE LOW VERSUS HIGH SERUM DCA SUBGROUPS These results are shown graphically, in different ways, in figs 3 and 4.

(i) Paired results, linking caecal and faecal $7 a-D H$ activities in the two subgroups (fig 3)

The same pattern of results, as that noted above when $7 \alpha-\mathrm{DH}$ activity was compared in paired caecal and faecal samples from all 20 individuals, was seen when the corresponding linked comparisons were made in the low and high serum DCA subgroups. Thus in the 10 individuals with "low" proportions of DCA in fasting serum (less than the median of $19.7 \%$ ), the mean $7 \alpha-\mathrm{DH}$ activity in "faeces" (3.75 $(1.25) \times 10^{-4} \mathrm{U} / \mathrm{mg}$ protein) was $29 \%$ less than that found in the caecum $\left(5.28(0.76) \times 10^{-4}\right.$ $\mathrm{U} / \mathrm{mg}$ protein $)$ in this study $(\mathrm{p}<0.01)$. Similarly, in the 10 patients with "high" percentages
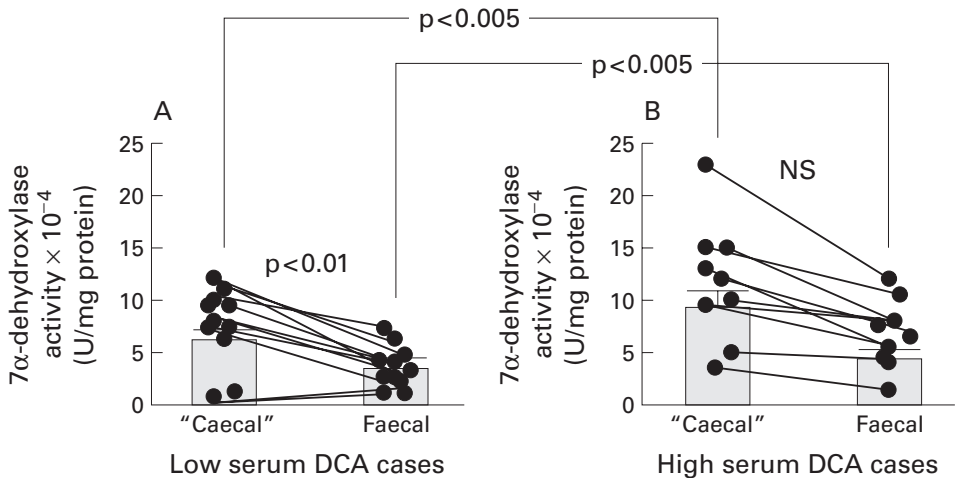

High serum DCA cases

Figure 3 Paired results linking "caecal" and faecal 7a-dehydroxylase activities in the low $(A)$ versus high $(B)$ serum deoxycholic acid $(D C A)$ subgroups: individual data points with means (SEM).
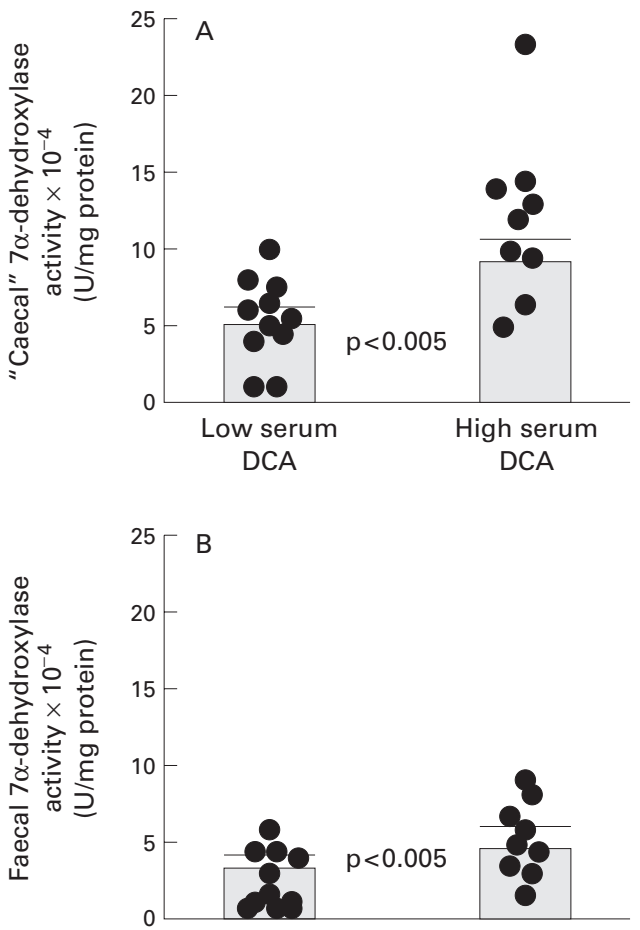

Figure 4 Non-paired results comparing "caecal" $(A)$ and faecal (B) 7a-dehydroxylase activities in the low versus high serum deoxycholic acid (DCA) subgroups: individual data points with means (SEM).

of DCA in fasting serum (greater than the median of $19.7 \%$ ), the mean $7 \alpha-\mathrm{DH}$ activity in faecal samples $\left(4.47 \quad(1.39) \quad \times 10^{-4} \quad \mathrm{U} / \mathrm{mg}\right.$ protein) was just under half $(45 \%)$ that found in the washout from the proximal colon $(9.84$ (0.9) $\times 10^{-4} \mathrm{U} / \mathrm{mg}$ protein). However, this difference was not statistically significant.

(ii) Non-paired results, comparing caecal and faecal $7 a-D H$ activities, in the two subgroups

Figure 4 compares $7 \alpha-\mathrm{DH}$ results in the low versus high serum DCA subgroups for caecal and faecal samples.

Mean caecal $7 \alpha-\mathrm{DH}$ activity in the high DCA subgroup (11.95 (1.68) $\times 10^{-4} \mathrm{U} / \mathrm{mg}$ protein) was $118 \%$ greater than that in the low DCA subgroup $\left(5.48 \quad(0.98) \times 10^{-4} \quad \mathrm{U} / \mathrm{mg}\right.$ protein; $\mathrm{p}<0.005)$. There was a similar pattern of results for faecal $7 \alpha-\mathrm{DH}$, the mean activity in the high DCA subgroup (9.27 (1.17) $\times 10^{-4}$ $\mathrm{U} / \mathrm{mg}$ protein) being $160 \%$ greater than that in patients with low serum DCA (3.56 (0.59) $\times 10^{-4} \mathrm{U} / \mathrm{mg}$ protein; $\mathrm{p}<0.005$ ).

\section{ENDOGENOUS CHOLIC ACID CONCENTRATION}

The paired data for CA concentrations in the caecal and faecal samples from all 20 individuals are shown in fig 5 .

As the results in fig 5 show, the concentration of CA in the caecal aspirates varied considerably from 0.14 to 1.65 with a mean of 1.08 $(0.14) \mu \mathrm{mol} / \mathrm{ml}$. As predicted however, in every case there was a marked and consistent $(\mathrm{p}<0.001)$ fall in CA concentration between the right and left halves of the colon such that CA was absent, or virtually so, in most of the "faecal" samples. Moreover, when we compared CA concentrations in the caecal aspirates 


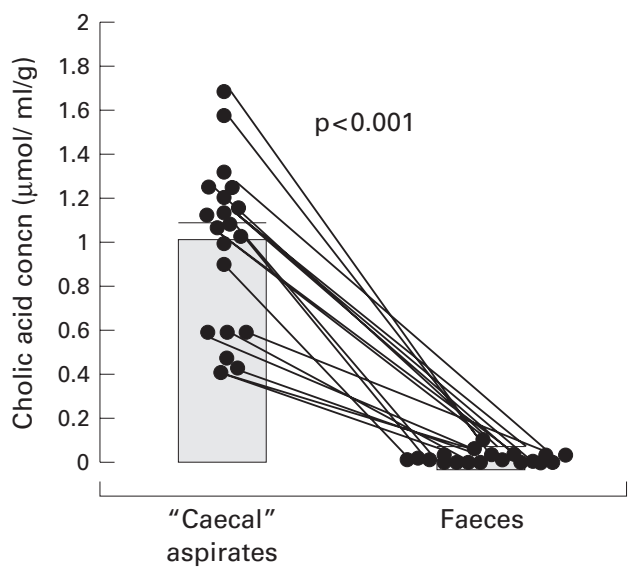

Figure 5 Endogenous cholic acid concentrations in paired "caecal" and faecal samples: individual data points with means (SEM).

Table 2 Cholic acid (CA) concentrations in caecal and "faecal" samples from the low and high serum deoxycholic acid (DCA) subgroups (see text)

\begin{tabular}{llll}
\hline & \multicolumn{3}{l}{$C A(\mu \mathrm{mol} / \mathrm{g} / \mathrm{ml}$ of sample) } \\
\cline { 2 - 4 } & $\begin{array}{l}\text { Low serum } \\
\text { DCA }\end{array}$ & $\begin{array}{l}\text { High serum } \\
\text { DCA }\end{array}$ & p Value \\
\hline $\begin{array}{l}\text { Caecal aspirate } \\
\text { "Faeces" }\end{array}$ & $\begin{array}{c}810.0(110.0) \\
3.0(1.0)\end{array}$ & $\begin{array}{c}1140.0(120.0) \\
3.0(2.0)\end{array}$ & NS \\
& & & \\
\hline
\end{tabular}

from the "low" and "high" serum DCA subgroups, mean CA concentrations were again significantly greater in the caecal aspirates than in the "faeces" (table 2).

RELATIONSHIP BETWEEN $7 \alpha-$ DH ACTIVITY AND CA CONCENTRATIONS IN THE CAECAL SAMPLES

When the relationship between the activity of $7 \alpha-\mathrm{DH}$ (U/mg protein) and endogenous CA concentration was studied in the caecal aspirates (fig 6), there was a weak $(r=0.58)$ but significant $(\mathrm{p}<0.005)$ linear correlation between the two variables. However, in the faecal samples there was no such significant relationship.

RELATIONSHIP BETWEEN $7 \alpha$-DH ACTIVITY AND SERUM DCA

There were significant linear relationships between the per cent DCA in fasting serum

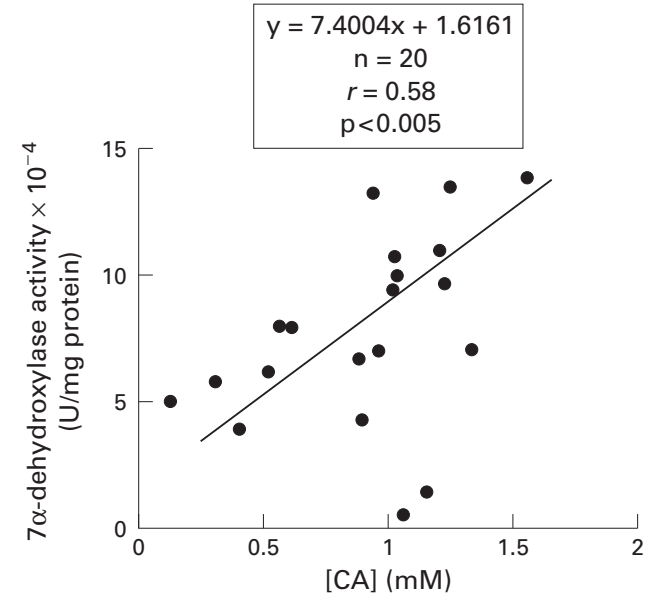

Figure 6 Relationship between 7a-dehydroxylase activity and cholic acid concentration in the "caecal" samples. and the activities of $7 \alpha-\mathrm{DH}$ in the caecal $(r=0.89)$ and faecal (0.65) samples: $\mathrm{p}<0.005$ at both sites.

\section{Discussion}

STUDY DESIGN

Although the broad aim of these studies was to compare various aspects of CA and DCA metabolism in caecal and faecal samples from the same individuals, as noted in the methods section the techniques used to sample colonic luminal contents have their limitations. Thus "caecal" samples were obtained endoscopically from a site somewhere proximal to the hepatic flexure. However, in the absence of fixed anatomical landmarks, it is difficult to be precise about the exact site of aspiration during clinical colonoscopy. Furthermore, although we refer throughout the paper to "faeces" it could be argued that the bile acid composition and the bacterial enzyme activities in material washed out from the left colon by a phosphate enema are not necessarily the same as those in freshly passed stools. Certainly the results of clinical and radiological studies show that formed faeces often linger in the descending and sigmoid colon for 24 hours or more, before they are evacuated. ${ }^{24}$ During that time, there could well be further changes in $7 \alpha-\mathrm{DH}$ activity (although probably not in CA concentrations as these were already almost zero in the enema washout material). Hence the results of the present study probably underestimate the magnitude of the differences in DCA metabolism between the right and left halves of the colon.

In this study, the CGH and $7 \alpha-\mathrm{DH}$ results were expressed as units of enzyme activity per mg protein in the colonic luminal contents. While we cannot assume that the protein of the caecal and faecal samples comes exclusively from bacteria, the fact that the $\mathrm{CGH}$ and $7 \alpha-\mathrm{DH}$ activities are expressed in $\mathrm{U} / \mathrm{mg}$ protein means that they approximate to enzyme specific activities - that is, the amounts of enzyme per bacterium.

DISTRIBUTION OF RESULTS FOR CGH AND 7 $\alpha-D H$ ACTIVITIES AT BOTH SAMPLING SITES

There is no obvious explanation for the non-Gaussian distribution of the $\mathrm{CGH}$ results at both colonic sampling sites. However, in the subgroup of four individuals with high caecal CGH activities (three of whom had cholesterol gall stones), the corresponding faecal samples also had relatively high levels of CGH activity. Moreover, in these four patients mean $7 \alpha-\mathrm{DH}$ activity both in the caecal aspirates (11.53 (4.01) $\times 10^{-4} \mathrm{U} / \mathrm{mg}$ protein) and in faeces (7.93 $(2.87) \times 10^{-4} \mathrm{U} / \mathrm{mg}$ protein) was also comparatively high, perhaps because high $\mathrm{CGH}$ activity yields high concentrations of unconjugated CA which in turn stimulate increased $7 \alpha-\mathrm{DH}$ activity by substrate-enzyme induction. ${ }^{1325}$ Whatever the reason for the non-Gaussian distribution of the results, the fact remains that there was no difference in $\mathrm{CGH}$ activities between caecal and faecal samples while there was an obvious and significant difference in $7 \alpha-\mathrm{DH}$ at these two sites. 
DIFFERENCES IN CGH AND $7 \alpha$-DH ACTIVITIES BETWEEN CAECAL AND FAECAL SAMPLES

There are at least two possible explanations for the different pattern of results for $\mathrm{CGH}$ and $7 \alpha-\mathrm{DH}$ activities between the right and left halves of the colon. Firstly, CGH is a ubiquitous enzyme present in many intestinal bacterial species-both aerobes and anaerobes. ${ }^{3}$ In contrast, CA $7 \alpha-\mathrm{DH}$ is found in only a few strains of Gram positive anaerobes ${ }^{2} 8$ and the number of these micro-organisms is relatively low in faeces. In fact, as shown by the results in figs 1 and 2 , the mean activity of CGH in the caecum was more than 200 times that of $7 \alpha-\mathrm{DH}$. Given the relative abundance of $\mathrm{CGH}$, it is unlikely to be rate limiting in the intestinal bacterial conversion of conjugated CA to unconjugated DCA whereas $7 \alpha-$ dehydroxylation might well be.

Secondly, $7 \alpha-\mathrm{DH}$ activity is known to be inducible by its substrate $\mathrm{CA}^{1325}$ while $\mathrm{CGH}$ is not. Thus in the caecum and ascending colon, although CA concentrations were variable, they were relatively high (up to $1.65 \mathrm{mM}$; fig 5) and linearly related to $7 \alpha-\mathrm{DH}$ activity (fig 6).

DISTRIBUTION OF RESULTS FOR ENDOGENOUS BILE ACID CONCENTRATIONS IN THE CAECUM (i) Primary bile acids

To test the substrate-enzyme hypothesis (by studying the relationship between CA concentration and $7 \alpha-\mathrm{DH}$ in the caecum), we were relying on spontaneous variations in caecal CA concentration, rather than on pharmacological manoeuvres designed to perturb the balance between CA and DCA by using broad spectrum antibiotics, ${ }^{829}$ drugs that increase or decrease the rates of transit through the intestine, ${ }^{3031}$ or regimens that change intracolonic $\mathrm{pH}$, such as oral lactulose. ${ }^{32} 33$ Instead, we relied on spontaneous variations in "endogenous" caecal CA concentrations which, in the event, ranged from 0.14 to $1.65 \mu \mathrm{mol} / \mathrm{ml}$ although the explanation for this scatter in results is unknown. Presumably it reflects either the "spillover" of conjugated CA (which has escaped absorption in the small intestine) into the colon or passage through the ileocaecal valve of unconjugated CA (which has been formed by deconjugation in the terminal ileum ${ }^{34}$ ), or both.

\section{(ii) Secondary bile acids}

Factors influencing the concentration of dehydroxylated bile acids (such as DCA and lithocholic acid) in the caecum are equally complex. Thus McJunkin et al found that dehydroxylated bile acids were present in the caecum, even in patients with diarrhoeal disorders. ${ }^{35}$ At first sight this might suggest that not only deconjugation but also dehydroxylation begins in the terminal ileum. Thus the presence of DCA in the proximal colon depends not only on deconjugation and dehydroxylation of the amidates of CA but also on deconjugation of recycled conjugated DCA and on absorption of the nascent secondary bile acid. Measurement of dehydroxylated bile acid concentrations in, and absorption from, the colon fell outside the aims of the present study.

SIMILARITIES AND DIFFERENCES BETWEEN CA CONCENTRATION AND $7 \alpha-D H$ ACTIVITY IN CAECAL AND FAECAL SAMPLES

Initially, there seems to be no a priori reason why apparently independent variables such as bile acid concentration and bacterial enzymatic activity should change in parallel from one region of the large bowel to the next. None the less, the fact that they did so raises three further points for discussion.

Firstly, the observation that CA concentrations are relatively high in caecum/proximal colon but are almost zero in the faeces/enema washout of the distal colon seems initially to confirm the results of many previous studies ${ }^{3} 14$ which showed that by the time of defecation only secondary (bacterially modified) bile acids remain in faeces. However, the disappearance of CA from the colonic luminal contents during large bowel transit is due not only to $7 \alpha$-dehydroxylation but also to CA absorption from the colon, mainly by passive non-ionic diffusion. ${ }^{26}$ As noted above, measurement of colonic bile acid absorption was not one of the objectives of the present study. Therefore, in the absence of the facts, we can only speculate about the relative contributions of $7 \alpha-$ dehydroxylation versus absorption to the decline of CA concentration during transit through the colon.

Secondly, the weak $(r=0.58)$ but significant $(p<0.005)$ linear relationship between CA concentration and $7 \alpha-\mathrm{DH}$ activity in the caecum is consistent with the concept of substrate enzyme induction. However, the fact that there is continuing $7 \alpha-\mathrm{DH}$ activity in the left colon, at a time when CA has virtually disappeared from the luminal contents, suggests that at least some of the dehydroxylating enzyme activity must be independent of its substrate.

Thirdly, the fact that $7 \alpha-\mathrm{DH}$ activity is found on both sides of the colon (albeit in significantly reduced amounts on the left), suggests that the $7 \alpha$-dehydroxylation pathway may be a pancolonic phenomenon. It also suggests that some DCA may be formed in, and absorbed from, the left colon. Indeed, based on the results of a multivariate analysis in our companion study ${ }^{15}$ we tentatively reached just this conclusion. However, it is worth emphasising that the presence of $7 \alpha-\mathrm{DH}$ activity in the luminal contents of the left colon cannot prove that the enzyme is biologically active there. Indeed, the precedent of a mismatch between the anatomical distribution of an enzyme's activity along the intestine and its maximal physiological site of action comes from studies of lactase activity in humans. ${ }^{27}$ Thus the peak activity of this disaccharidase is in the mid small bowel while the principal physiological site of lactose hydrolysis is normally in the duodenum and upper jejunum. 
RESULTS IN “HIGH” VERSUS “LOW” SERUM DCA SUBGROUPS

The validity of dividing the 20 individuals retrospectively into two subgroups ("high" and "low" serum DCA) based on results above and below the median for per cent DCA in fasting serum is also open to question. In fact, as indicated in the methods section, absolute values for serum DCA concentrations were all within the normal range. ${ }^{28}$ None the less, the decision to divide patients on this basis (in much the same way that Berr and colleagues ${ }^{8}$ had done previously) unmasked interesting and significant differences in mean caecal and faecal $7 \alpha-\mathrm{DH}$ activities between the two subgroups.

Interpretation of the observation that patients in the high serum DCA subgroup also had high $7 \alpha-\mathrm{DH}$ activities is also open to question. However, the implication of the results in fig 4 is that high activities of $7 \alpha-\mathrm{DH}$ in both the right and left halves of the colon are associated with high percentages of DCA in fasting serum (and, by inference, high proportions of this bile acid in bile $\mathrm{e}^{3637}$ and in the bile acid pool ${ }^{38}$ ).

RELATIONSHIP BETWEEN ANAEROBIC INTESTINAL BACTERIA, $7 \alpha$-DH ACTIVITY, AND DCA

METABOLISM

The aims of the present study did not include measurements of anaerobic bacteria in intestinal contents or comparisons of results between stone free controls and gall stone patients. Instead, these were the objectives of our companion paper ${ }^{15}$ in which we showed (among other things) that mean caecal $7 \alpha-\mathrm{DH}$ activity in gall stone patients was significantly greater than in stone free "controls". Based on this and other evidence, we speculated that the principal mechanism for increased DCA formation in gall stone patients was due not to an increase in $7 \alpha-\mathrm{DH}$ specific activity but to an increase in the numbers of total and Gram positive anaerobes (and therefore to an attendant increase in the total amount or biomass of the $7 \alpha$-dehydroxylating enzymes in the colon). To prove this, one would need to carry out faecal dilution assays, which were not performed in the present study. However, from the results in our companion study, ${ }^{15}$ we know that high $\mathrm{CGH}$ and $7 \alpha-\mathrm{DH}$ "specific activities" (such as those found in the subgroup of patients described here) are not significantly related to anaerobic bacterial counts.

\section{Conclusions}

Our results confirm that there are obvious regional differences in bile acid metabolism between the right and left halves of the colon. Therefore, one logical conclusion is that future studies of bile acid metabolising enzymes should be based on caecal/right colonic contents rather than on faeces. From a scientific standpoint, this conclusion is incontrovertible. However, the caecum and proximal colon are relatively inaccessible, and their contents cannot be sampled non-invasively whether by colonoscopy, peroral intubation, or during surgery, Moreover, although the right-left differences in colonic luminal CA concentrations were marked, those for $7 \alpha-\mathrm{DH}$ activity, although statistically significant, were modest. In addition, the activity of $7 \alpha-\mathrm{DH}$ in faeces usually, but not always, predicted its activity in the right colon. From a pragmatic standpoint therefore, it seems reasonable to conclude that sampling fresh faeces is an acceptable compromise for clinical studies of DCA metabolism.

This work was supported in part by grants from the John Ellerman Foundation and Novartis Pharma, Basel, Switzerland, to whom the authors are grateful. This work was presented in part at the 1998 Annual Scientific meeting of the British Society of Gastroenterology, and published in abstract form (Gut 1998;42(Suppl 1):A1 1).

1 Nair PP, Gordon M, Reback J. The enzymatic cleavage of the carbon-nitrogen bond in $3 \alpha, 7 \alpha, 12 \alpha$-trihydroxy-5 $\beta$ -

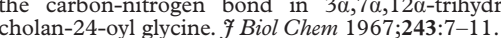

2 Stellwag EJ, Hylemon PB. $7 \alpha$ dehydroxylation of cholic acid and chenodeoxycholic acid by Clostridium leptum. $\mathcal{F}$ Lipid Res 1979;20:325-33.

3 Hill MJ, Drasar BS. Degradation of bile salts by human intestinal bacteria. Gut 1968;9:22-7.

4 Aries VC, Crowther JS, Drasar BS, et al. Degradation of bile salts by human intestinal bacteria. Gut 1969;10:575-6.

5 Gustafsson BE, Midtvedt T, Norman A. Isolated faecal micro-organisms capable of $7 \alpha$ dehydroxylating bile acids. f Exp Med 1966;123:413-32.

6 Ferrari A, Pacini N, Canzi E, et al. Prevalence of oxygen intolerant micro-organisms in primary bile acid $7 \alpha$ dehydroxylating mouse intestinal microflora. Curr Microbiol 1980;4:257-60

7 Doerner KC, Takamine F, LaVoie CP, et al. Assessment of faecal bacteria with bile acid $7 \alpha$ dehydroxylase activity for the presence of bai-like genes. Appl Environ Microbiol 1997; 63:1185-8.

8 Berr F, Kullack-Ublick GA, Paumgartner G, et al. $7 \alpha$ dehydroxylating bacteria enhance deoxycholic acid input and cholesterol saturation of bile in patients with gallstones. Gastroenterology 1996;111:1611-20.

9 Bentley DW, Nichols RL, Condon RE, et al. The microflora of the human ileum and intra-abdominal colon: Results of direct needle aspiration at surgery and evaluation of the technique. F Lab Clin Med 1972;79:421-9.

10 Evans DF, Pye G, Bramley R, et al. Measurement of gastrointestinal $\mathrm{pH}$ profiles in normal ambulant human subjects. Gut 1988;29:1035-41.

11 Fallingborg J, Christensen LA, Ingeman-Nielson M, et al. $\mathrm{pH}$ profile and regional transit times of the normal gut measured by a radiotelemetry device. Aliment Pharmacol Ther 1989;3:605-13.

12 Fadden K, Owen RW. Faecal steroids and colorectal cancer: the effect of lactulose on faecal bacterial metabolism in a continuous culture model of the large intestine. Eur f Cancer Prev 1992;1:13-27.

cer Prev 1992;1:13-27.
13 White BA, Lipsky RH, Fricke RJ, et al. Bile acid induction specificity of 7 alpha dehydroxylase activity in an intestinal Epecificity of 7 alpha dehydroxylase activity in

14 Gustafsson BE, Bergstrom S, Lindstedt S, et al. Turnover and nature of faecal bile acids in germfree and infected rats fed cholic acid-24-14C. Proc Soc Exp Biol Med 1957;94: $467-71$

5 Thomas LA, Bathgate T, Veysey MJ, et al. Prolonged colonic transit, increased bacterial enzymes and higher luminal $\mathrm{pH}$ enhance deoxycholic acid formation in cholesterol gallstone disease. Gastroenterology 2000;119:806-15.

16 Murray RK, Granner DK, Mayer PA, et al. Harper's Biochemistry, 2nd edn. New York: Appleton and Lange, 1988:55-6.

17 Thomas LA, King A, French GL, et al. Cholylglycine hydrolase and $7 \alpha$ dehydroxylase: optimum assay conditions in vitro and caecal enzyme activities ex vivo. Clin Chim Acta 1997;268:61-72.

18 Rodriques CMP, Setchell KDR. Performance characterisRodriques $\mathrm{CMP}$, Setchell KDR. Performance characteris-
tics of reverse-phase bonded silica cartridges for serum bile tics of reverse-phase bonded silica cartridges for

19 Eneroth P. Thin layer chromatography of bile acids. 7 Lipid Res 1963;4:11-16.

20 Bruusgaard A. Quantitative determination of the major 3-hydroxy bile acids in biological material after thin-layer chromatographic separation. Clin Chim Acta 1970;28:495504.

21 Goto J, Watanabe K, Miura H, et al. Trace analysis of bile acids by gas chromatography-mass spectrometry with negative ion chemical ionisation detection. f Chromatogr 1987;388:379-87.

22 Stellaard F, Langelaar A, Kok RM, et al. Determination of plasma bile acids by capillary gas-liquid chromatographyelectron capture negative chemical ionisation mass fragmentography. $\mathcal{F}$ Lipid Res 1989;30:1647-52.

23 Setchell KDR, Matsui A. Serum bile acid analysis. Clin Chim Acta 1983;127:1-17.

24 Torsoli A, Ramorino ML, Ammaturo MV, et al. Mass movements and intracolonic pressures. Am f Dig Dis 1971;16: 693-6.

25 Mallonee DH, Adams JL, Hylemon PB. The bile acid inducible baiB gene from Eubacterium strain sp. VPI 
12708 encodes a bile acid coenzyme A ligase. 7 Bacteriol 1992;174:2065-71.

26 Samuel P, Saypol GM, Meilman E, et al. Absorption of bile acids from the large bowel in man. 7 Clin Invest $1968: 47: 2070-8$.

27 Newcomer AD, McGill DB. Distribution of disaccharidase activity in the small bowel of normal and lactase deficien subjects. Gastroenterology 1966;51:481-8.

28 Ahlberg J, Angelin B, Bjorkhem I, et al. Individual bile acids in portal venous and systemic blood serum in fasting man. Gastroenterology 1977;73:1377-82.

29 Low-Beer TS, Nutter S. Colonic bacterial activity, biliary cholesterol saturation and pathogenesis of gallstones. Lancet 1978;2:1063-5.

30 Veysey MI, Malcolm P, Mallet AI, et al. Effects of cisapride or gall bladder emptying, intestinal transit, and serum deoxycholate: a prospective, randomised, double blind, placebo controlled trial. Gut 2001;49:828-34.

31 Marcu SN, Heaton KW. Intestinat transit, dexcholic acid and the cholesterol saturation of bile-three inter-related factors. Gut 1986;27:550-8.

32 Nagengast FM, Hectors MPC. Inhibition of secondary bile acid formation in the large intestine by lactulose in healthy subjects of two different age groups. Eur 7 Clin Invest 1988; 18:56-61.

33 Thornton JR, Heaton KW. Do colonic bacteria contribute to cholesterol gallstone formation? Effects of lactulose on bile. BMF 1981;282:1018-20.

34 Northfield TC, McColl I. Postprandial concentrations of free and conjugated bile acids down the length of the normal human small intestine. Gut 1973;14:513-18.

35 McJunkin B, Fromm H, Sarva RP, et al. Factors in the mechanism of diarrhea in bile acid malabsorption: fecal pH-a key determinant Gastroenterology 1981;80:1454pH-

36 Nagengast FM, Van Munster IP, Salemans JMJI. Deoxycholic acid metabolism in patients with adenomas. Gastroenterology 1993;105:955-6.

37 Lindor KD, Lacerda MA, Jorgensen RA. Relationship between biliary and serum bile acids and response to ursodeoxycholic acid in patients with primary biliary cirrhosis. Am f Gastroenterol 1998;93:1498-504.

38 Versey MJ, Thomas LA, Mallet AI, et al. Colonic transit influences deoxycholine acid kinetics. Gastroenterology 2001;121:812-22.

\section{Gut through the ages}

Browse the Archive

Gut online has an archive of content dating back to 1966 .

Full text from 1997; abstracts from 1975; table of contents from 1966

www.gutjnl.com 